\title{
A new catfish, Hara koladynensis from northeastern India (Siluriformes: Erethistidae)
}

\author{
N. Anganthoibi ${ }^{1} \&$ W. Vishwanath ${ }^{2}$ \\ 1,2 Department of Life Sciences, Manipur University, Canchipur, Manipur 795003, India \\ Email: ${ }^{1}$ angannong@gmail.com; ${ }^{2}$ wvnath @ gmail.com (corresponding author)
}

Date of publication (online): 26 September 2009 Date of publication (print): 26 September 2009 ISSN 0974-7907 (online) | 0974-7893 (print)

Editor: Heok Hee $\mathrm{Ng}$

\section{Manuscript details:}

Ms \# 02271

Received 06 July 2009

Final received 22 August 2008

Finally accepted 31 August 2009

Citation: Anganthoibi, N. \& W. Vishwanath (2009) A new catfish, Hara koladynensis from northeastern India (Siluriformes: Erethistidae). Journal of Threatened Taxa 1(9): 466-470.

Copyright: ( $)$ N. Anganthoibi \& W. Vishwanath 2009. Creative Commons Attribution 3.0 Unported License. JoTT allows unrestricted use of this article in any medium for non-profit purposes, reproduction and distribution by providing adequate credit to the authors and the source of publication.

Author Details: N. AngantholbI is a Project Fellow under a project funded by the National Bureau of Fish Genetic resources, Lucknow. She is working on the inventory of the catfishes of North East India and their phylogenetic analysis. She is undergoing $\mathrm{PhD}$ on a relevant topic in the Department of Life Sciences, Manipur University.

W. VISHWanath is a Professor in the Department of Life Sciences, Manipur University. His field of specialization is fish and fisheries. He is presently engaged in taxonomy and systematics of freshwater fishes of northeastern India.

Author Contribution: The sudy: NA - survey, collection, morphometric and anatomic study of catfishes of northeastern India and their phylogenetics; WV - supervision of taxonomy and phylogeny of freshwater fishes of northeastern India. Current paper: NA - detailed examination of the erethistid catfishes of northeastern India and comparison with specimens in ZSI, Kolkata and data of the related species of neighbouring countries, establish identity of new species; WV - supervision in establishing new species and discuss taxonomic status.

Acknowledgements: The authors are grateful to Maurice Kottelat for providing literature and to the director, ZSI, Kolkata, for permission to examine the type of Hara horai. The work is supported by catfish inventory and phylogeny project sanctioned by National Bureau of Fish Genetic Resources, Lucknow.
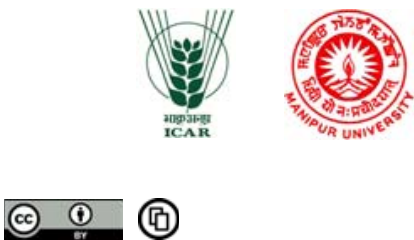

OPEN AGCESS | FREE DOWNLOAD
Abstract: A new Erethistid catfish species, Hara koladynensis is described from Koladyne River, Mizoram, India. It is distinguished from its congeners in having rough (vs. smooth or serrated) anterior margin of dorsal spine; shorter pre-anal length (58.5-60.9\% SL vs. 63.2-75.2), longer head (36.0-38.3\% SL vs. 24.8-34.2\%), longer post-adipose distance (18.6-21.9\% SL vs. 12.3-18.3), and deeper body (21.9-25.2\% SL vs. 11.5-20.9).

Keywords: New species, Erethistidae, catfish, Mizoram, India

\section{INTRODUCTION}

Fishes of the genus Hara Blyth of the family Erethistidae are characteristic in having a stumpy body, unidirectional denticles along the outer margin of pectoral fin, externally smooth and internally serrated dorsal fin and a thorax with no adhesive apparatus (Hora 1950). It is also characterized in having coracoid with ventral anterior process, pectoral spine with serrated anterior margin, antero-ventral flange on the ventral surface of the complex centrum and the parapophysis of the fifth vertebra with a vertical lamina (de Pinna 1996). The genus includes small to medium sized catfishes having brown cryptic colouration and heavily tuberculate skin inhabiting hill streams in the subhimalayan region and western Indochina ( $\mathrm{Ng} \&$ Kottelat 2007).

Hamilton (1822) described Pimelodus hara from Hooghly River, India. Hora (1950) considered the species as a representative of the genus Hara. Hara buchanani Blyth (1860) and Pimelodus asperus McClelland (1844) are now considered junior synonyms of H. hara ( $\mathrm{Ng} \&$ Kottelat 2005; Ferraris 2007).

Day (1870) described Hara jerdoni from Sylhet district, Bangladesh. Misra (1976) described H. horai from Terai and Duars, West Bengal. Ng \& Kottelat (2007) described H. longissima, H. minuscula and H. spinulus from Myanmar and H. mesembrina, H. filamentosa from Thailand. They also treated H. saharsai Munshi \& Srivastava (1988) and $H$. serrata Vishwanath \& Kosygin (2000) as junior synonyms of H. hara. Thus eight species of Hara are known so far.

A recent collection of fishes from Koladyne River, Mizoram, India included a new Hara species which is herein described as H. koladynensis.

\section{Material and Methods}

Measurements were made on the left side of specimens with dial calipers to the nearest $0.1 \mathrm{~mm}$ following $\mathrm{Ng} \&$ Kottelat (2007). Head length (HL) and measurements of body parts are presented as proportions of standard length (SL) and subunits of head as of head length (HL). Numbers in parentheses following meristic data denote number of specimens examined with that count. Osteological structures were observed in cleared and alizarin stained specimens. Vertebral counts followed Roberts (1989). Two paratypes of $H$. koladynensis $(\mathrm{SL}=56.4 \& 58.0 \mathrm{~mm}$ ) were dissected for osteology. Fin rays were counted under a stereo-zoom light microscope. Type specimens are deposited in the Manipur University Museum of Fishes (MUMF).

\section{Hara koladynensis sp. nov. (Image 1a,b \& c)}

Type material

Holotype: 25.iv.2008, $22^{\circ} 23^{\prime} \mathrm{N} \& 92^{\circ} 57^{\prime} \mathrm{E}, 54.5 \mathrm{~mm}$ SL; Koladyne River at Kolchaw, Lawntlai District, Mizoram, India, coll. Nebeshwar \& party, MUMF 10001.

Paratypes: 5 exs., 54.4-65.8 mm SL; data as for holotype, MUMF 10002. 

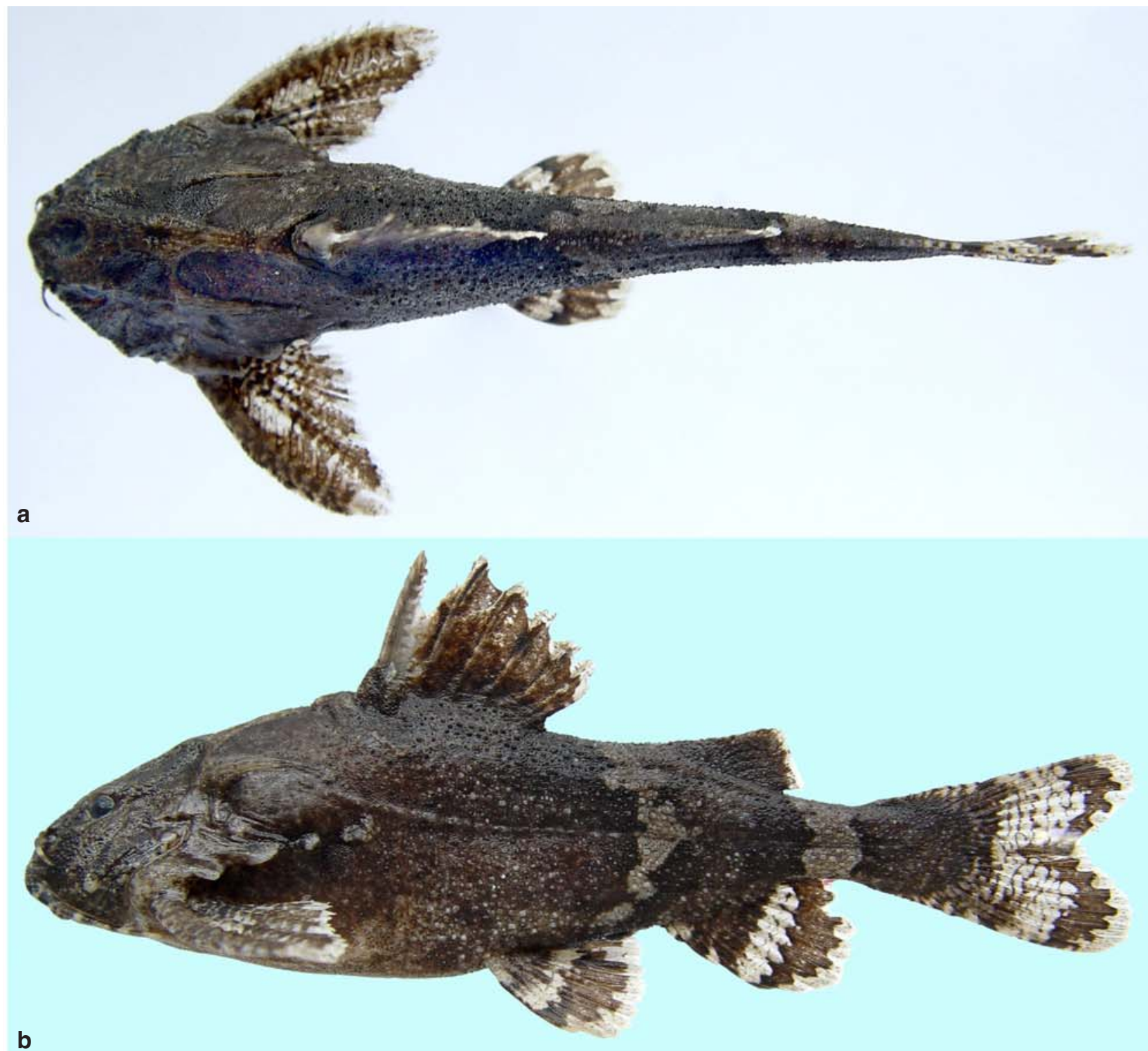

b

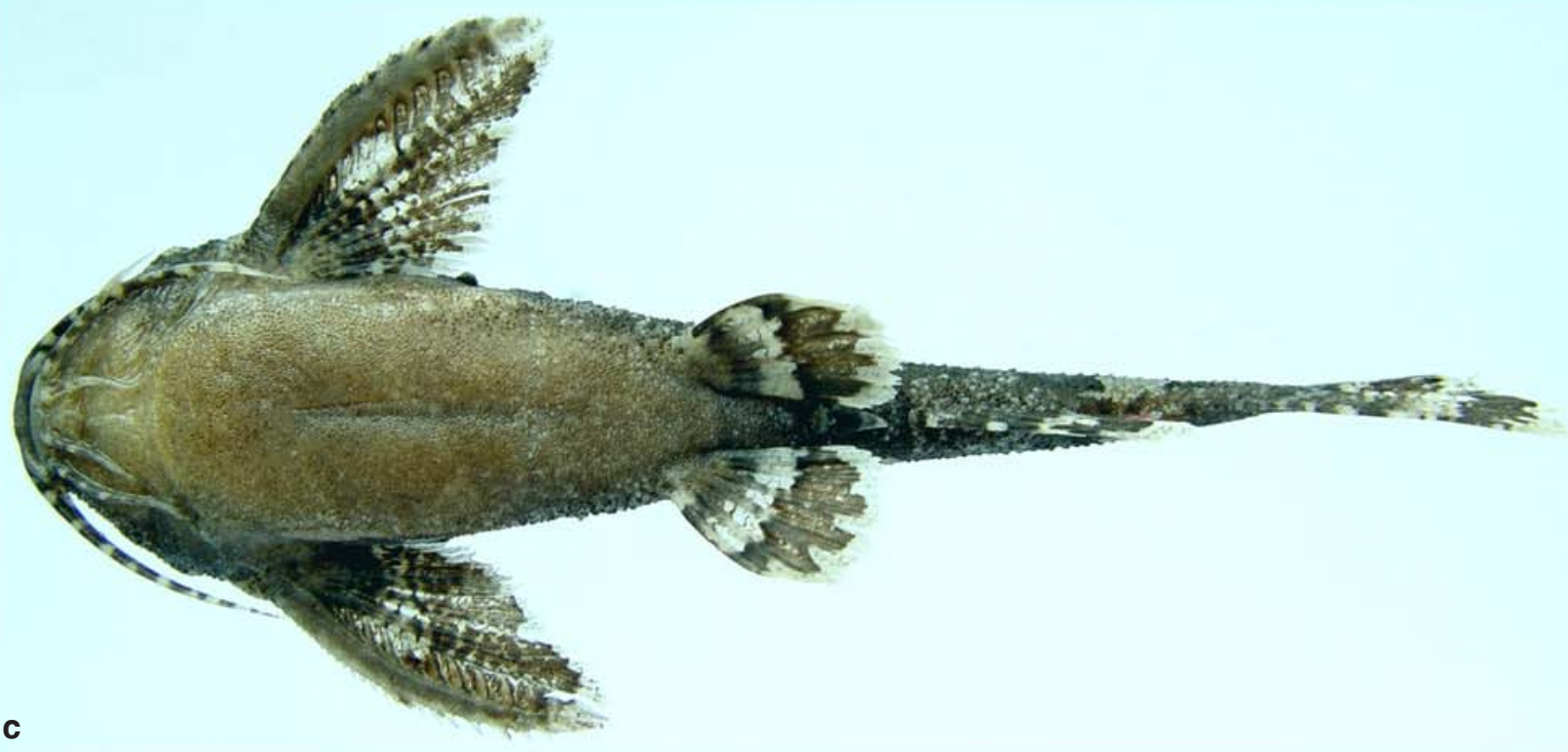

Image 1. Hara koladynensis sp. nov., MUMF 10001, holotype, 54.5mm SL

a - dorsal; b - lateral; c - ventral views 
Table 1. Morphometric data for Hara koladynensis sp. nov. $(n=6)$

\begin{tabular}{|c|c|c|c|c|}
\hline$\% S L$ & $\begin{array}{l}\text { Holotype } \\
\text { MUMF } 10001\end{array}$ & $\begin{array}{l}\text { Range } \\
\text { (paratypes) }\end{array}$ & mean & SD \\
\hline Predorsal length & 44.0 & $39.1-44.0$ & 42.3 & 1.7 \\
\hline Preanal length & 59.6 & $58.5-60.9$ & 59.6 & 1.1 \\
\hline Prepelvic length & 55.0 & $51.6-55.0$ & 53.0 & 1.4 \\
\hline Prepectoral length & 27.5 & $20.4-27.5$ & 23.9 & 2.7 \\
\hline Length of dorsal fin base & 18.3 & $17.5-20.5$ & 19.1 & 1.3 \\
\hline Dorsal spine length & 16.5 & $16.1-20.0$ & 17.7 & 1.6 \\
\hline Anal fin length & 11.9 & 11.9-13.9 & 12.7 & 0.8 \\
\hline Pelvic fin length & 16.5 & $16.5-18.7$ & 17.5 & 1.0 \\
\hline Pectoral fin length & 30.3 & $25.2-31.3$ & 29.0 & 2.7 \\
\hline Pectoral spine length & 27.8 & 28.9-31.0 & 26.3 & 3.2 \\
\hline Caudal fin length & 31.0 & $30.2-32.3$ & 30.1 & 1.0 \\
\hline Length of adipose fin base & 15.7 & $14.5-17.5$ & 16.1 & 1.0 \\
\hline Dorsal to adipose distance & 11.0 & $11.0-15.5$ & 13.4 & 1.6 \\
\hline Post-adipose distance & 21.8 & $18.6-21.9$ & 20.5 & 1.5 \\
\hline Caudal peduncle length & 20.9 & $18.8-21.8$ & 21.0 & 1.1 \\
\hline Caudal peduncle depth & 9.2 & $8.5-9.5$ & 9.0 & 0.4 \\
\hline Body depth at anus & 22.0 & $21.9-25.2$ & 23.5 & 2.3 \\
\hline Head length & 37.0 & $36.0-38.3$ & 37.0 & 1.0 \\
\hline Head width & 31.5 & $27.7-32.0$ & 31.0 & 1.6 \\
\hline Head depth & 27.8 & 26.3-30.6 & 28.6 & 1.8 \\
\hline Length of posterior process on coracoid & 25.1 & $23.4-27.0$ & 25.3 & 1.5 \\
\hline \multicolumn{5}{|l|}{$\% \mathrm{HL}$} \\
\hline Snout length & 37.6 & $35.2-44.2$ & 38.3 & 3.2 \\
\hline Interorbital distance & 32.6 & $30.0-33.8$ & 32.3 & 1.5 \\
\hline Eye diameter & 14.8 & $11.5-17.5$ & 14.4 & 2.0 \\
\hline Nasal barbel length & 22.7 & $13.8-22.7$ & 18.4 & 2.9 \\
\hline Maxillary barbel length & 64.4 & $55.7-69.5$ & 63.5 & 4.8 \\
\hline Inner mandibular barbel length & 30.6 & $30.6-35.5$ & 33.7 & 1.8 \\
\hline Outer mandibular barbel length & 37.6 & $37.6-45.0$ & 42.5 & 2.6 \\
\hline
\end{tabular}

\section{Diagnosis}

Hara koladynensis is distinguished from its congeners by the following combination of characters: rough (vs. smooth or serrated) anterior margin of dorsal spine; longer head (36.0$38.3 \%$ SL vs. 24.8-34.2) and post-adipose distance (18.6-2 1.9\% SL vs. 12.3-18.3); deeper body (21.9-25.2\% SL vs. 11.5-20.9) and shorter preanal length (58.5-60.9\% SL vs. 63.2-75.2).

\section{Description}

Morphometric data are shown in Table 1. Body robust, moderately compressed laterally. Dorsal profile gently curved from tip of snout to level of nares, then sloping steeply to the origin of dorsal fin and evenly sloping ventrally to the end of caudal peduncle. Ventral profile roughly straight and flat upto origin of pelvic fin, then gently sloping dorsally to the end of caudal peduncle. Head ventrally compressed and longer than width. Supraoccipital process long reaching anterior tip of nuchal plate. Eyes moderate, superior in position.

Snout narrow, profile dorsally curved and rounded when viewed laterally and acutely triangular when viewed from above. Snout with pronounced steepening of curvature anteriorly at level of posterior nares when viewed laterally. Anterior and posterior opening of nares large and separated by flap of skin comprising base of nasal barbel. Gill opening narrow, extending ventrally upto the level of base of coracoid process. Bony elements of dorsal surface of head very prominent and covered with thin tuberculate skin.

Barbels in four pairs. Maxillary barbel when adpressed extend beyond the base of the pectoral spine. Nasal barbel short, subtending by a flap of skin at base and extending to midway between posterior edge of posterior nares and anterior margin of orbit. Anterior mandibular barbel when adpressed reaching the anterior base of pectoral spine; posterior mandibular, when adpressed reaching the gill opening.

Mouth inferior, premaxillary tooth band not exposed when mouth is closed. Upper lip with indistinct plicae. Oral teeth small and villiform, in irregular rows on all tooth-bearing surfaces. Premaxillary teeth in single crescentic band across midline. Palate edentulous. Dentary teeth in two narrow crescentic bands separated at midline. Anus and urogenital openings located straight through posterior three quarters of adpressed pelvic fin. Skin tuberculated, distributed evenly throughout head and body. Lateral line complete and mid lateral. Vertebrae $15+17=32(2)$. Dorsal fin located above anterior third of body, with I,5,i (6) rays. Dorsal spine moderately long and gently curved backward with rough anterior margin, posterior margin with 5-6 serrae. Adipose fin with anterior margin straight and posterior margin angular. Caudal fin with i,7,7,i (5) or i,6,7,i (1) principal rays. Lower lobe of caudal fin slightly longer than the upper lobe. Analfin base approximately in line with adipose-fin base. Anal fin with iii, 7 (6) rays. Pelvic fin with i,4,i (1) or i,5 (5) rays. Pectoral fin with I,6,i rays; anterior margin with 15-25 small distally directed serrations, posterior margin with 7-12 large medially directed serrations. Coracoid with well developed posterior processes, extending to two thirds distance between base of posteriormost pectoral-fin ray and pelvic-fin origin.

Coloration: Head and body dark chestnut to dark chocolate brown. Belly and ventral surface of head light brown, that of head lighter and creamish. Two thin irregular light brown bars on body; first chevron-shaped and located between dorsal and adipose-fin bases, second thicker than first located on caudal peduncle. Dorsal fin dark brown except for thin hyaline distal margin. Pectoral fin brown with thin hyaline distal margin and either a small ovoid hyaline spot or a crescentic median hyaline band on middle third of fin. Pelvic and anal fins 


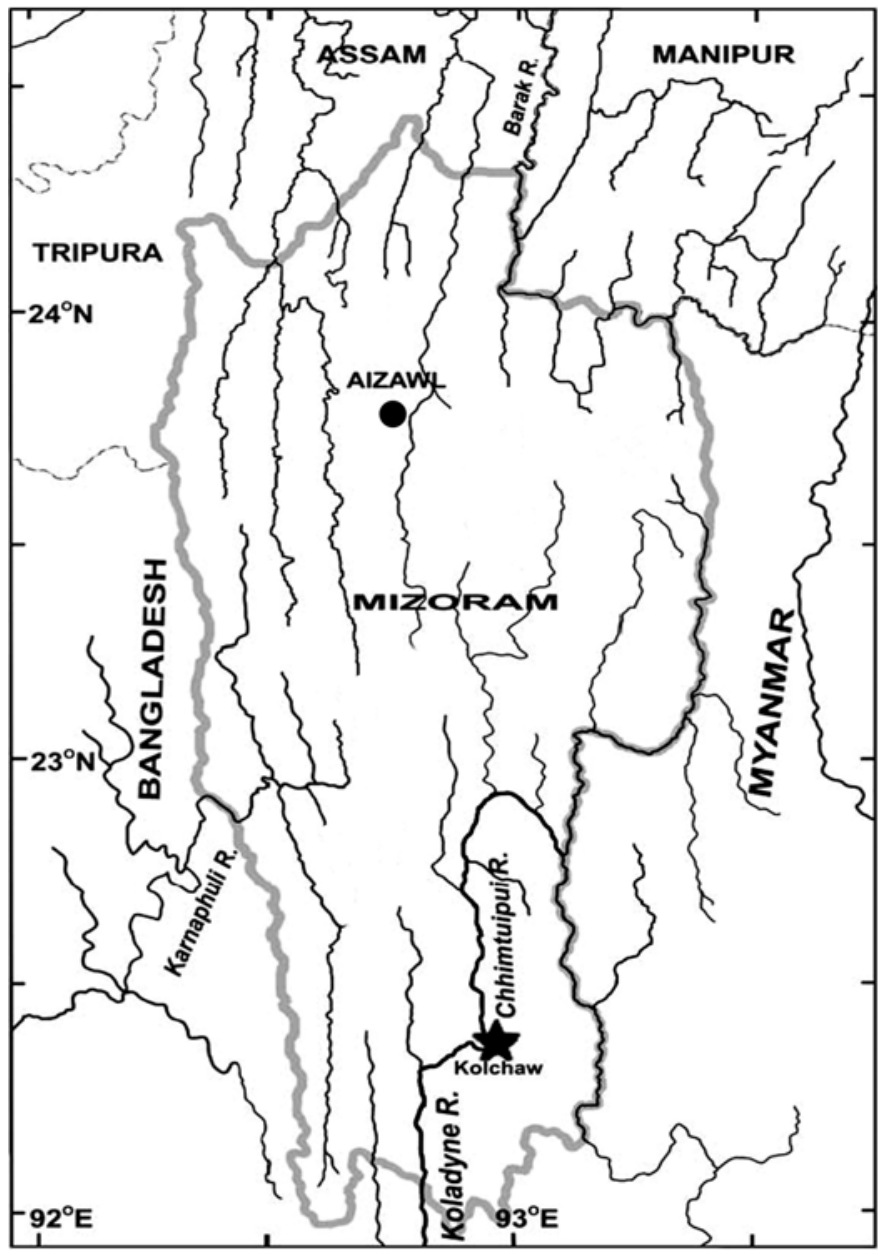

Figure 1. Map of Mizoram showing type locality (star) of Hara koladynensis sp. nov.

hyaline, with dark brown bases and subdistal stripes. Adipose fin brown as in body, with lighter coloured distal margin. Caudal fin hyaline, with irregular W-shaped band subdistally and with small dark brown flecks randomly distributed throughout fin. Maxillary and mandibular barbel light brown, with dark brown annuli.

\section{Etymology}

The species is named after Koladyne River, Mizoram, India, its type locality.

\section{Distribution}

Presently known from Koladyne River at Mizoram, India (Fig. 1).

\section{Discussion}

Hara koladynensis is easily distinguished from its congeners by the combination of characters mentioned in diagnosis. The new species also differs from $H$. jerdoni in having longer caudal peduncle (18.8-21.8\% SL vs. 14.9-15.4) and shorter pectoral spine (28.9-31.0\% SL vs. 42.2-51.7); from H. horai in having wider eye diameter (11.5-17.5\% HL vs. 8.0-9.0) and from both the species in having longer caudal fin (30.2-32.2\% SL vs.20.527.9).

Hara koladynensis further differs from H. hara in having rough (vs. serrated) anterior margin of dorsal spine; shorter maxillary barbel (55.7-69.5\% HL vs. 80.8-108.2) and dorsal spine (16.120.0\% SL vs. 22.7-27.4); from H. minuscula in having shorter posterior process on coracoid (23.4-27.0\% SL vs. 29.5-32.3) and inner mandibular barbel (30.6-35.6\% HL vs. 40.0-57.1); from $H$. spinulus in having shorter inner mandibular barbel (30.6-35.5\% HL vs. 43.1-53.7), longer caudal peduncle (18.8$21.8 \%$ SL vs. $11.8-15.0)$ and post-adipose distance (18.6-21.9\% SL vs. 12.4-17.7) and from all of them in having shorter outer mandibular barbel (37.6-45.0\% SL vs. 52.1-73.8). The new species can also be distinguished from both H. mesembrina and $H$. longissima in having absence (vs. presence) of a filamentous extension of the first principal ray of upper caudal fin lobe, from $H$. longissima in having shorter inner mandibular barbel (30.6-35.5\% HL vs. 40.7-50.3), outer mandibular barbel (37.645.0\% HL vs. 53.5-72.3) and dorsal spine (16.1-20.0\% SL vs. 22.6-26.7) and from $H$. filamentosa in having longer posterior coracoid process (23.4-27.0\% SL vs. 19.9-22.8).

Most of the highly specialized rheophilic fish species in Southeast Asia have restricted distribution ranges (Kottelat 2001). Hara koladynensis is found in the Koladyne River (also known as Kaladan or Chimtuipui) which originates from the western face of Chin Hills in Myanmar bordering Mizoram and Manipur states of India. At Kolchaw, the river bottom is rocky and the water current is very fast. The river is not connected with Ganga-Brahmaputra and Chindwin-Irrawaddy drainages as it is respectively separated by the Chittagong hill tract and the Arakan Yoma hill range. The isolated habitat is expected to support many endemic species including the new species.

\section{Comparative material}

Hara filamentosa: Data from $\mathrm{Ng} \&$ Kottelat (2007).

Hara hara; MUMF 2508, 2509, 7054, 7055, 48-60 mm SL, Jiri R., tributary of Barak R., Manipur, India; MUMF 2507, 58.3 $\mathrm{mm}$ SL, Barak R., Manipur, India. Additional data from $\mathrm{Ng}$ \&Kottelat (2007).

Hara horai; ZSI - FF955 (neotype), 56.1 mm SL; Terai \& Duars, $\mathrm{N}$. Bengal. Additional data from $\mathrm{Ng} \&$ Kottelat (2007).

Hara jerdoni: Data from Ng \&Kottelat (2007).

Hara longissima: Data from $\mathrm{Ng} \&$ Kottelat (2007).

Hara mesembrina: Data from $\mathrm{Ng}$ \&Kottelat (2007).

Hara minuscula: Data from Ng \&Kottelat (2007).

Hara spinulus: Data from $\mathrm{Ng} \&$ Kottelat (2007).

\section{References}

Blyth, E. (1860). Report on some fishes received chiefly from the Sitang River and its tributary streams, Tenasserim provinces. Journal of Asiatic Society, Bengal 28(2): 138-174.

Munshi, J.S.D. \& M.P. Srivastava (1988). Natural history of fishes and systematic of freshwater fishes of India. Narendra Publishing House, Delhi, 403pp.

Day, F. (1870). Notes on the genus Hara. Journal of the Asiatic society of Bengal 39: 37-40.

de Pinna, M.C.C. (1996). A phylogenetic analysis of the Asian catfish families Sisoridae, Akysidae and Amblycipitidae, with a hypothesis on the relationships of the neotropical Aspredinidae (Teleostei, Ostariophysi). Fieldiana Zoology (new series) 84:1-83.

Ferraris, C.J. Jr. (2007). Checklist of catfishes, recent and fossil (Osteichthyes: Siluriformes), and catalogue of siluriform primary types. Zootaxa 418: 1-628.

Hamilton, F. (1822). An account of the fishes found in the river Ganges and its 
branches. Archibald Constable, Edinburgh and Hurst, Robinson, London, 405 pp.

Hora, S.L. (1950). Siluroid fishes of India, Burma and Ceylon. XIII Fishes of the genera Erethistes Muller and Troschel, Hara Blyth and of two new allied genera. Records of the Indian Museum 47: 183-202.

Kottelat, M. (2001). Fishes of Laos. Wildlife Heritage Trust, Colombo, $198 \mathrm{pp}$.

McClelland, J. (1844). Description of a collection of fishes made at Chusan and Ningpo in China, by Dr. G.R. Playfair, Surgeon of the Phlegethon, war streamer, during the late military operations in that country. Calcutta journal of Natural History and Miscellany of the Arts and Sciences in India 4: 390-413.

Misra, K.S. (1976). The fauna of India and adjacent countries. Pisces. Vol. III. Teleostomi: Cypriniformes; Siluri. Zoological Survey of India, Calcutta, $367 \mathrm{pp}$.

Ng, H.H. \& M. Kottelat (2005). Cealatoglanis zonatus, a new genus and species of the Erethistidae (Teleostei: Siluriformes) from Myanmar, with comments on the nomenclature of Laguvia and Hara species. Ichthyological Exploration of Freshwaters 16(10): 13-22.

Ng, H.H. \& M. Kottelat (2007). A review of the catfish genus Hara, with the description of four new species (Siluriformes: Erithistidae). Revue Suisse de zoologie 114(3): 471-505.

Roberts, T. (1989). The freshwater fishes of Western Borneo (Kalimantan, Barat, Indonesia). Memoirs of California Academy of Science 14: 1210.

Vishwanath, W. \& L. Kosygin (2000). On a new species of the genus Hara Blyth from Manipur, India. Indian Journal of Fisheries 47: 143147 . 